\title{
Extracts difference citronella (Cymbopogon Winterianus Jowitt) and Seeds Soursop (Annona muricata $L$ ) as the Repellent Aedes Aegypti Mosquito
}

\author{
Cici Apriza Yanti ${ }^{1}$, Mila Sari ${ }^{2}$ \\ \{ciciaprizayanti@fdk.ac.id ${ }^{1}, \underline{\left.\text { milasari@fdk.ac.id }{ }^{2}\right\}}$ \\ Public Health Departement STIKes Fort De Kock Bukittinggi, West Sumatera, Indonesia ${ }^{1,2}$
}

\begin{abstract}
Dengue Haemorrhagic Fever (DHF) is one of several infectious diseases. Efforts should be made to protect themselves from the bite of themosquito vector Aedes aegypti by using a repellent made from natural lemongrass (Cymbopogon Winterianus Jowitt) and soursop seeds (Annona muricata $L$ ). The purpose of this study was to determine the effectiveness of the two ingredients mentioned above as a natural respondent. This research is experimental with the independent variable concentration of citronella extract (concentration $75 \%, 60 \%, 45 \%, 30 \%, 15 \%$ ) and soursop seed extract with concentrations of $20 \%, 40 \%, 60 \%, 80 \%$ and $100 \%$. The sample of this study was Aedes aegypti mosquitoes 500. This study uses 5 repetitions for 6 hours of observation. The test used is the Anova test and the Independent Test T Test. The results showed the most effective concentration of fragrant lemongrass extract was a concentration of $75 \%$ with a total of 8 tails at the 5 th hour with a protective power of $92.26 \%$. Soursop seed extract at a concentration of $100 \%$ with the number of larvae that died 5 observations had a protective power of $95.42 \%$. Based on the results it was concluded that the fragrant lemongrass extract was effective against the protection power of Aedes aegypti mosquitoes with a concentration of $100 \%$, so that the lemongrass can be recommended as a repellent.
\end{abstract}

Keywords: Dengue Fever, Seeds Soursop, citronella extract, repellent.

\section{Introduction.}

Dengue Haemorrhagic Fever (DHF) or Dengue Haemorhagic Fever (DHF) is one of several infectious diseases that are a health problem in the world, especially in developing countries. In Indonesia, this disease mainly attacks in urban areas (urban), but it does not rule out also attacking in rural areas (rural). In 2011 to August there were 24,362 cases with 196 deaths (CFR: $0.80 \%$ ). The spread of dengue is increasingly widespread, until 2013 as many as 498 regencies / cities in Indonesia have been endemic of DHF. [1] The development of DHF cases at the global 
level is increasing, as reported by the World Health Organization (WHO) which is from 980 cases in almost 100 countries in 1954-1959 to 1,016,612 cases in almost 60 countries in 20002009 (WHO, 2014). In West Sumatra, City Regencies that have been infected by dengue have increased every year until 2016. It is known that the number of Regencies / Cities in West Sumatra is 19 Regencies / Cities. In 2014, there were 18 districts / cities affected by DHF, in 2015 there were 18 districts / cities and in 2016 there were 19 districts / cities. This increase shows that every City District in West Sumatra has been infected with DHF-[2].

The number of DHF sufferers per regency / city in West Sumatra in 2014 was 2,282 cases with 12 deaths $(I R=45.75$ per 100,000 population and CFR $=1 \%$ ). During 2014 there were approximately 4 regencies / cities that reported outbreaks, namely Padang City, Lima Puluh Kota District, Padang Pariaman District, Tanah Datar District, Sijunjung Regency. Pasaman is ranked 9th out of 19 regencies / cities in West Sumatra with a total of 67 dengue cases. [3]

In the City of Bukittinggi for the occurrence of Dengue Hemorrhagic Fever in 2014 there were 139 cases of DHF, in 2015 dengue cases decreased to 99 cases, but in 2016 cases of DHF in Bukittinggi City were 106 cases with CFR 0.02\% (IR 84.99 per 100,000 population). And in 2017 the number of DHF cases decreased again, namely 69 cases. Whereas for 2018 from January to June there were 59 cases of DHF in Bukittinggi City. [4].

The incidence of DHF which always increases every year in various regions, including the city of Bukittinggi, so that efforts are needed in avoiding mosquito bites such as the use of mosquito repellent (repellent). Currently the recommended repellent is $N$, N-diethylmetatoluamide (DEET) as the ingredient active. DEET can repel mosquitoes, mites / ticks and orthophoda otherif applied to the skin and clothing [5]. Currently, almost all repellent drugs in the form of lotions on the market contain DEET. DEET has a very good repellent power but in its use it can cause hypersensitivity and irritation. [6] DEET concentrations of up to $50 \%$ are recommended for adults and children over 2 months and lower concentrations do not last long in the body so it is necessary for replication. [5].

Reppelent use also includes the use of excessive and insecticides which repeated can have undesirable effects such as environmental pollution. One way to obtain environmentally friendly chemicals is to utilize natural potential, namely, plants that contain bioinsecticides. Currently, almost all repellent drugs in the form of lotions on the market contain DEET. DEET has a very good repellent power but in its use it can cause hypersensitivity and irritation. [6]. The mosquito repellent currently recommended is one that contains $N$, N-diethylmetatoluamide (DEET) as an as an ingredient active. DEET can repel mosquitoes, mites / orthophoda other if applied to the skin and clothing. [5]

The use of reppelent which uses chemicals such as $N, N$-diethylmetatoluamide (DEET) in a long time will cause disturbances on the skin, such as dry skin and itching. So it is necessary to look for natural reppelent ingredients such as from plants. Plants that can be used to reppelent mosquitoes are citronela plants because they contain substances such as geraniol, metal heptenon, terpenes, terpenes, alcohols, acids organic and especially citronella. This cause soil essential citronellacan be used as a repellent by providing protection against mosquito bites. [7]

Other plants that can be used as mosquito repellent are soursop seeds. Soursop seeds contain 42-45\% essential oil [8] (Kardinan, 2004). According to Ardraviz (2012) [9] that seeds, bark, stems and soursop roots contain secondary metabolite compounds namely alkaloids. [10] said that the bioactive content contained in soursop seeds is ancompound alkaloid consisting of acetogenin and annonaine [11] in Tohir (2010) [12] suggesting that soursop seeds contain bioactive acetogenin, a compound that is an insecticide and food inhibitor (anti-feedant). Based on the description above, this study aims to test the extract of lemongrass and soursop seeds as a 
repellent for mosquito bites.

\section{Method}

This research is experimental in which Aedes aegypti mosquitoes adult female receive direct treatment. Aedes aegypti was put into an observation cage with a size of $50 \mathrm{~cm} \times 30 \mathrm{~cm}$ x $30 \mathrm{~cm}$ then put the hands that had been smeared with citronella extract (Cymbopogon winterianus Jowitt) and hands smeared with soursop seeds (Annona Muricata L) with various concentrations. The design of this study is the posttest only control group design. The number of mosquito samples Aedes aegypti per observation cage was 20 individuals. In this research there are 10 groups of experiments that will have 10 repetitions, then the number of probandus is 10 people so that the number of samples needed is 1000 mosquitoes. This research was conducted at the Central Laboratory of Science, Fort De Kock College of Health Sciences. When the research will be carried out in July - August 2018.

\subsection{Tool and Material citronella exstract (Cymbopogon winterianus Jowitt)}

Citronela extract (Cymbopogon winterianus Jowitt) from Pasaman Regency which is cultivated by the community and distilled using the method Water and Steam Distillation. Water is put into the kettle up to $1 / 3$ part. Then the material is put into the kettle until it is solid and tightly closed. When boiled and boiling water, the steam that is formed will pass through a small hole through the holes and through the crevices of essential oil contained in the material along with the hot steam through the pipe to the condenser kettle. Then the water vapor and oil will condense and be accommodated in a separation tank. Separate the oil and store it in a dark closed container and store it in a room that is not exposed to direct sunlight.

\subsection{Tool and Materal Soursop seed (Annona Muricata L)}

Soursop Seeds are cleaned, dried by aerated in the open air protected from sunlight for 7 days until completely dry there is no water content. After drying, then ground / mashed. Weigh soursop seeds that have been refined as much as 500 grams and then soaked insolvent ethanol $96 \%$ in a ratio of $1: 3(\mathrm{w} / \mathrm{v})$. Put in the microwave for 20 minutes at medium temperature. Then left for $1 \mathrm{x}$ 24 hours. After $1 \times 24$ hours then filtered with filter paper, the results of filtering in the oven for 5 days at a temperature of $40^{\circ} \mathrm{C}$, so that ethanol evaporates to produce a thick extract that is ready for use.

\section{Result}

\subsection{Protection Power of Fragrant citronella Extract and soursop Seed Extract}

Research on the effectiveness of citronella extract (Cymbopogon winterianus jowitt) and Soursop seed extract (Annona muricata) against the protection power of Aedes aegypti mosquitoes has been carried out in July - August 2018 at the Central Laboratory of Science STIKes Fort De Kock Bukittinggi from 08.00 to 13.00 WIB. This research uses the object of 3-5 day old adult female mosquito obtained from the hatching of mosquito eggs obtained from the P2B2 Batu Raja Research and Development Center. This research was assisted by 5 (five) probandus people.

\section{1) Protection Power of citronella}


Tabel I . Protection Power of Citronela Extract

\begin{tabular}{|c|c|c|c|c|c|c|c|c|c|c|c|c|}
\hline \multirow{3}{*}{$\mathbf{R}$} & \multicolumn{12}{|c|}{ Treatment Time } \\
\hline & \multicolumn{2}{|c|}{$0^{\text {th }}$ Hour } & \multicolumn{2}{|c|}{$1^{\text {st }}$ Hour } & \multicolumn{2}{|c|}{$2^{\text {nd }}$ Hour } & \multicolumn{2}{|c|}{$3^{\text {rd }}$ Hour } & \multicolumn{2}{|c|}{$4^{\text {th }}$ Hour } & \multicolumn{2}{|c|}{$5^{\text {th }}$ Hour } \\
\hline & $\mathbf{T}$ & $\mathbf{C}$ & $\mathbf{T}$ & $\mathrm{C}$ & $\mathbf{T}$ & $\mathrm{C}$ & $\mathbf{T}$ & $\mathrm{C}$ & $\mathbf{T}$ & $\mathrm{C}$ & $\mathbf{T}$ & $\mathrm{C}$ \\
\hline \multicolumn{13}{|c|}{ Concentration $75 \%$} \\
\hline 1 & 0 & 102 & 0 & 100 & 3 & 104 & 3 & 94 & 6 & 99 & 7 & 100 \\
\hline 2 & 0 & 112 & 0 & 109 & 1 & 98 & 2 & 98 & 8 & 92 & 8 & 110 \\
\hline 3 & 0 & 132 & 0 & 96 & 2 & 90 & 4 & 99 & 6 & 117 & 6 & 106 \\
\hline 4 & 0 & 101 & 1 & 108 & 2 & 94 & 2 & 111 & 9 & 98 & 10 & 99 \\
\hline 5 & 0 & 103 & 0 & 112 & 3 & 119 & 2 & 101 & 7 & 107 & 9 & 102 \\
\hline Mean & 0 & 110 & 0 & 105 & 2 & 101 & 3 & 101 & 7 & 103 & 8 & 103 \\
\hline PP \% & \multicolumn{2}{|c|}{100} & \multicolumn{2}{|c|}{99,81} & \multicolumn{2}{|c|}{97,22} & \multicolumn{2}{|c|}{97,41} & \multicolumn{2}{|c|}{92,98} & \multicolumn{2}{|c|}{92,26} \\
\hline \multicolumn{13}{|c|}{ Concentration $60 \%$} \\
\hline 1 & 1 & 106 & 3 & 110 & 5 & 85 & 5 & 114 & 7 & 106 & 13 & 100 \\
\hline 2 & 1 & 119 & 5 & 118 & 2 & 92 & 3 & 120 & 5 & 99 & 14 & 109 \\
\hline 3 & 2 & 122 & 3 & 88 & 3 & 102 & 2 & 96 & 9 & 102 & 11 & 96 \\
\hline 4 & 1 & 99 & 4 & 117 & 2 & 88 & 6 & 117 & 6 & 129 & 9 & 128 \\
\hline 5 & 1 & 118 & 5 & 98 & 2 & 92 & 4 & 120 & 7 & 118 & 13 & 120 \\
\hline Mean & 1 & 113 & 4 & 106 & 3 & 92 & 4 & 113 & 7 & 111 & 10 & 111 \\
\hline PP \% & \multicolumn{2}{|c|}{99,42} & \multicolumn{2}{|c|}{98,21} & \multicolumn{2}{|c|}{96,67} & \multicolumn{2}{|c|}{92,14} & \multicolumn{2}{|c|}{91,91} & & \\
\hline & & & & & Con & trati & $45 \%$ & & & & & \\
\hline 1 & 0 & 97 & 1 & 96 & 3 & 105 & 7 & 103 & 8 & 121 & 11 & 122 \\
\hline 2 & 0 & 101 & 2 & 89 & 3 & 97 & 10 & 105 & 5 & 102 & 10 & 118 \\
\hline 3 & 1 & 114 & 2 & 92 & 5 & 89 & 9 & 97 & 8 & 103 & 13 & 109 \\
\hline 4 & 1 & 117 & 1 & 119 & 3 & 95 & 7 & 92 & 13 & 109 & 10 & 94 \\
\hline 5 & 1 & 96 & 3 & 108 & 2 & 94 & 6 & 99 & 9 & 97 & 8 & 104 \\
\hline Mean & 1 & 105 & 2 & 101 & 3 & 96 & 8 & 99 & 9 & 106 & 11 & 109 \\
\hline PP (\%) & & & & & & & & & & & & \\
\hline & & & & & Con & trati & $30 \%$ & & & & & \\
\hline 1 & 1 & 105 & 4 & 94 & 3 & 105 & 5 & 103 & 17 & 70 & 20 & 97 \\
\hline 2 & 3 & 111 & 6 & 98 & 3 & 88 & 4 & 110 & 20 & 118 & 24 & 110 \\
\hline 3 & 3 & 110 & 3 & 99 & 7 & 115 & 5 & 73 & 15 & 78 & 22 & 85 \\
\hline 4 & 2 & 121 & 7 & 111 & 5 & 97 & 9 & 99 & 15 & 107 & 18 & 123 \\
\hline 5 & 1 & 90 & 5 & 129 & 8 & 107 & 7 & 108 & 13 & 78 & 23 & 103 \\
\hline Mean & 2 & 107 & 5 & 106 & 5,2 & 102 & 6 & 99 & 16 & 90 & 21 & 104 \\
\hline PP (\%) & & & & & & & & & & & & \\
\hline & & & & & Con & ratic & $5 \%$ & & & & & \\
\hline 1 & 2 & 103 & 6 & 93 & 10 & 116 & 14 & 96 & 47 & 115 & 58 & 88 \\
\hline 2 & 3 & 115 & 8 & 108 & 11 & 104 & 13 & 101 & 53 & 93 & 62 & 101 \\
\hline 3 & 2 & 117 & 9 & 103 & 18 & 87 & 16 & 114 & 52 & 98 & 66 & 89 \\
\hline 4 & 4 & 122 & 9 & 89 & 14 & 90 & 15 & 127 & 49 & 103 & 59 & 117 \\
\hline 5 & 2 & 90 & 4 & 103 & 9 & 94 & 17 & 96 & 55 & 78 & 62 & 94 \\
\hline Mean & 3 & 110 & 7 & 99 & 12 & 98 & 15 & 107 & 51 & 97 & 61 & 97 \\
\hline DP (\%) & & & & & & & & & & & & \\
\hline
\end{tabular}

Note $: \mathbf{R}=$ Repitition, $\mathbf{C}=$ Control, $\mathbf{T}=$ Treatment, $\mathbf{P P}=$ Protection Power

Based on table 1, above the average number of mosquitoes that landed on the hand treated at a $75 \%$ concentration at the 0th hour the number increased to hours 5 . The treatment at a concentration of $60 \%$ at the 0 th hour increases to the 5 th hour. While the protective power at a concentration of $45 \%$ at the $0^{\text {th }}$ to the $5^{\text {th }}$ hour decreases every hour. Protection power at a 
concentration of $30 \%$ from $0^{\text {th }}$ to $5^{\text {th }}$ hours decreases every hour. Protection power at a concentration of $15 \%$ at 0 to 5 hours decreases every hour.

\section{2) Protection Power Soursop Seed}

Table 2: Protection Power Soursop Seed

\begin{tabular}{|c|c|c|c|c|c|c|c|c|c|c|c|c|}
\hline \multirow{3}{*}{$\mathbf{R}$} & \multicolumn{12}{|c|}{ Treatment Time } \\
\hline & \multicolumn{2}{|c|}{$0^{\text {th }}$ Hour } & \multicolumn{2}{|c|}{$\mathbf{1}^{\text {st }}$ Hour } & \multicolumn{2}{|c|}{$2^{\text {nd }}$ Hour } & \multicolumn{2}{|c|}{$3^{\text {rd }}$ Hour } & \multicolumn{2}{|c|}{$4^{\text {th }}$ Hour } & \multicolumn{2}{|c|}{$5^{\text {th }}$ Hour } \\
\hline & $\mathbf{C}$ & $\mathbf{T}$ & $\mathbf{C}$ & $\mathbf{T}$ & $\mathbf{C}$ & $\mathbf{T}$ & $\mathbf{C}$ & $\mathbf{T}$ & $\mathbf{C}$ & $\mathbf{T}$ & $\mathbf{C}$ & $\mathbf{T}$ \\
\hline \multicolumn{13}{|c|}{ Concentration $100 \%$} \\
\hline 1 & 40 & 0 & 39 & 0 & 40 & 1 & 40 & 1 & 39 & 2 & 40 & 1 \\
\hline 2 & 39 & 0 & 40 & 0 & 40 & 1 & 40 & 1 & 40 & 1 & 39 & 2 \\
\hline 3 & 40 & 0 & 41 & 1 & 39 & 0 & 39 & 2 & 38 & 1 & 39 & 2 \\
\hline 4 & 40 & 0 & 40 & 0 & 40 & 0 & 39 & 1 & 39 & 2 & 40 & 3 \\
\hline 5 & 40 & 0 & 40 & 0 & 39 & 1 & 40 & 2 & 39 & 1 & 38 & 1 \\
\hline Mean & 40 & 0 & 40 & 0 & 40 & 1 & 40 & 1 & 39 & 1 & 39 & 2 \\
\hline $\mathrm{PP} \%$ & \multicolumn{2}{|c|}{100.0} & \multicolumn{2}{|c|}{99.5} & \multicolumn{2}{|c|}{98.5} & \multicolumn{2}{|c|}{96.5} & \multicolumn{2}{|c|}{96.4} & \multicolumn{2}{|c|}{95.4} \\
\hline \multicolumn{13}{|c|}{ Concentration $80 \%$} \\
\hline 1 & 40 & 0 & 39 & 0 & 40 & 1 & 40 & 1 & 39 & 2 & 40 & 1 \\
\hline 2 & 39 & 0 & 40 & 0 & 40 & 1 & 40 & 1 & 40 & 1 & 39 & 2 \\
\hline 3 & 40 & 0 & 41 & 1 & 39 & 0 & 39 & 2 & 38 & 1 & 39 & 2 \\
\hline 4 & 40 & 0 & 40 & 0 & 40 & 0 & 39 & 1 & 39 & 2 & 40 & 3 \\
\hline 5 & 40 & 0 & 40 & 0 & 39 & 1 & 40 & 2 & 39 & 1 & 38 & 1 \\
\hline Mean & 40 & 0 & 40 & 0 & 40 & 1 & 40 & 1 & 39 & 1 & 39 & 2 \\
\hline $\mathrm{PP} \%$ & \multicolumn{2}{|c|}{97.5} & \multicolumn{2}{|c|}{96.5} & \multicolumn{2}{|c|}{95.9} & \multicolumn{2}{|c|}{93.9} & \multicolumn{2}{|c|}{93.3} & \multicolumn{2}{|c|}{92.9} \\
\hline \multicolumn{13}{|c|}{ Concentration $60 \%$} \\
\hline 1 & 40 & 1 & 40 & 2 & 40 & 1 & 40 & 3 & 39 & 4 & 39 & 4 \\
\hline 2 & 40 & 1 & 39 & 2 & 39 & 2 & 40 & 3 & 40 & 5 & 40 & 5 \\
\hline 3 & 40 & 1 & 40 & 1 & 40 & 1 & 40 & 2 & 38 & 4 & 39 & 4 \\
\hline 4 & 40 & 2 & 40 & 2 & 39 & 3 & 40 & 3 & 40 & 3 & 40 & 3 \\
\hline 5 & 40 & 2 & 41 & 1 & 39 & 2 & 40 & 3 & 39 & 3 & 40 & 4 \\
\hline Mean & 40 & 1 & 40 & 2 & 39 & 2 & 40 & 3 & 39 & 4 & 40 & 4 \\
\hline $\mathrm{PP} \%$ & \multicolumn{2}{|c|}{96.5} & & & & & & & & & & \\
\hline & & & & & onc & rati & $40 \%$ & & & & & \\
\hline 1 & 40 & 2 & 40 & 2 & 39 & 3 & 40 & 3 & 40 & 5 & 40 & 6 \\
\hline 2 & 41 & 2 & 40 & 2 & 40 & 2 & 40 & 4 & 39 & 5 & 40 & 5 \\
\hline 3 & 40 & 2 & 41 & 3 & 41 & 3 & 39 & 4 & 40 & 4 & 40 & 6 \\
\hline 4 & 41 & 4 & 40 & 2 & 40 & 4 & 40 & 3 & 40 & 5 & 40 & 7 \\
\hline 5 & 40 & 2 & 40 & 3 & 40 & 3 & 40 & 4 & 39 & 5 & 41 & 6 \\
\hline Mean & 40 & 2 & 40 & 2 & 40 & 3 & 40 & 4 & 40 & 5 & 40 & 6 \\
\hline PP (\%) & & & & & & & & & & & & \\
\hline & & & & & onc & ati & $20 \%$ & & & & & \\
\hline 1 & 40 & 7 & 39 & 7 & 40 & 8 & 40 & 9 & 39 & 12 & 40 & 14 \\
\hline 2 & 39 & 6 & 40 & 7 & 39 & 8 & 40 & 9 & 40 & 13 & 40 & 15 \\
\hline
\end{tabular}




\begin{tabular}{ccccccccccccc}
3 & 40 & 6 & 41 & 7 & 39 & 9 & 39 & 8 & 38 & 14 & 39 & 15 \\
4 & 41 & 10 & 40 & 8 & 40 & 8 & 39 & 9 & 40 & 14 & 40 & 16 \\
5 & 40 & 6 & 40 & 6 & 39 & 7 & 40 & 10 & 39 & 11 & 39 & 16 \\
Mean & 40 & 7 & 40 & 7 & 39 & 8 & 40 & 9 & 39 & 13 & 40 & 15 \\
\hline PP $(\%)$ & 82.5 & 82.5 & 79.7 & 77.3 & 67.3 & \multicolumn{2}{c}{61.6} \\
\hline Note : R = Repitition, $\mathbf{C}=$ Control, $\mathbf{T}=$ Treatment, PP $=$ Protection Power
\end{tabular}

Protection power of soursop seed extract concentration of $100 \%$ highest $100 \%$ at 0 hour, while the lowest is $95.4 \%$ at hour 5 . The protection power of soursop seed extract concentration was the highest $80 \% 97.5 \%$ at 0 hours, while the lowest was $92.9 \%$ at 5 hours. The protection power of soursop seed extract concentration was $60 \%$ highest at $96.5 \%$ at 0 hours, while the lowest was $89.9 \%$ at 05 . The protection power of the soursop seed extract concentration is the highest $40 \% 94.1 \%$ at 0 hours, while the lowest is $85.1 \%$ at the 5 th hour. The protective power of the soursop seed extract concentration is the highest $20 \% 82.5 \%$ at $0^{\text {th }}$ hours, while the lowest is $61.6 \%$ at $5^{\text {th }}$ Hour.

\subsection{Effectiveness Citronela Extract and Soursop Seed Extract as Repplent}

1) Effectiveness Citronela Extract (Cympogon Winterianus Jowitt) as reppelent Tabel 3: Effectiveness Citronela Extract (Cymbopogon winterianus jowitt)

\begin{tabular}{|c|c|c|c|c|c|}
\hline 0 $^{\text {th }}$ Hour & $\begin{array}{c}\text { Concentration } \\
(\%) \\
\end{array}$ & Mean & SD & $95 \%$ CI & $p$ value \\
\hline 1 & 100 & 100,00 & 0,00 & $100,00 \mathrm{~s} / \mathrm{d} 100,00$ & \multirow{5}{*}{0,0005} \\
\hline 2 & 60 & 99,45 & 0,51 & $98,81 \mathrm{~s} / \mathrm{d} 100,08$ & \\
\hline 3 & 45 & 98,94 & 0,33 & $98,53 \mathrm{~s} / \mathrm{d} 99,36$ & \\
\hline 4 & 30 & 98,17 & 0,85 & $97,12 \mathrm{~s} / \mathrm{d} 99,23$ & \\
\hline 5 & 15 & 97,65 & 0,62 & $96,88 \mathrm{~s} / \mathrm{d} 98,41$ & \\
\hline \multicolumn{6}{|l|}{$1^{\text {st }}$ Hour } \\
\hline 1 & 75 & 99,81 & 0,41 & $99,30 \mathrm{~s} / \mathrm{d} 100,32$ & \multirow{5}{*}{0,0005} \\
\hline 2 & 60 & 98,18 & 0,83 & $97,14 \mathrm{~s} / \mathrm{d} 99,22$ & \\
\hline 3 & 45 & 96,22 & 0,91 & $95,08 \mathrm{~s} / \mathrm{d} 97,35$ & \\
\hline 4 & 30 & 95,28 & 1,43 & $93,49 \mathrm{~s} / \mathrm{d} 97,06$ & \\
\hline 5 & 15 & 92,68 & 2,36 & $89,74 \mathrm{~s} / \mathrm{d} 95,61$ & \\
\hline \multicolumn{6}{|l|}{$2^{\text {nd }}$ Hour } \\
\hline 1 & 75 & 97,84 & 0,69 & $96,97 \mathrm{~s} / \mathrm{d} 98,71$ & \multirow{5}{*}{0,0005} \\
\hline 2 & 60 & 96,63 & 1,32 & $94,98 \mathrm{~s} / \mathrm{d} 98,26$ & \\
\hline 3 & 45 & 96,91 & 1,59 & $94,93 \mathrm{~s} / \mathrm{d} 98,89$ & \\
\hline 4 & 30 & 95,00 & 1,90 & $92,64 \mathrm{~s} / \mathrm{d} 97,36$ & \\
\hline 5 & 15 & 86,99 & 5,06 & $80,71 \mathrm{~s} / \mathrm{d} 93,28$ & \\
\hline \multicolumn{6}{|l|}{$3^{\text {rd }}$ Hour } \\
\hline 1 & 75 & 97,38 & 0,96 & $96,18 \mathrm{~s} / \mathrm{d} 98,59$ & \multirow{5}{*}{0,0005} \\
\hline 2 & 60 & 92,14 & 1,51 & $90,26 \mathrm{~s} / \mathrm{d} 94,03$ & \\
\hline 3 & 45 & 96,51 & 1,27 & $94,93 \mathrm{~s} / \mathrm{d} 98,09$ & \\
\hline 4 & 30 & 93,81 & 2,07 & $91,23 \mathrm{~s} / \mathrm{d} 96,39$ & \\
\hline 5 & 15 & 85,79 & 2,23 & $83,02 \mathrm{~s} / \mathrm{d} 88,57$ & \\
\hline \multicolumn{6}{|l|}{$4^{\text {th }}$ Hour } \\
\hline 1 & 75 & 92,87 & 1,74 & $90,71 \mathrm{~s} / \mathrm{d} 95,04$ & \multirow{5}{*}{0,0005} \\
\hline 2 & 60 & 91,90 & 2,67 & $88,58 \mathrm{~s} / \mathrm{d} 95,22$ & \\
\hline 3 & 45 & 93,78 & 1,64 & $91,74 \mathrm{~s} / \mathrm{d} 95,83$ & \\
\hline 4 & 30 & 81,77 & 3,85 & $76,98 \mathrm{~s} / \mathrm{d} 86,55$ & \\
\hline 5 & 15 & 46,19 & 11,13 & $32,37 \mathrm{~s} / \mathrm{d} 60,02$ & \\
\hline
\end{tabular}




\begin{tabular}{|c|c|c|c|c|c|}
\hline \multicolumn{6}{|c|}{$5^{\text {th }}$ Hour } \\
\hline 1 & 75 & 92,22 & 1,72 & $90,09 \mathrm{~s} / \mathrm{d} 94,36$ & \multirow{5}{*}{0,0005} \\
\hline 2 & 60 & 90,45 & 1.71 & $88,32 \mathrm{~s} / \mathrm{d} 92,57$ & \\
\hline 3 & 45 & 88,96 & 2,41 & $85,96 \mathrm{~s} / \mathrm{d} 91,96$ & \\
\hline 4 & 30 & 78,94 & 4,09 & $73,86 \mathrm{~s} / \mathrm{d} 84,02$ & \\
\hline 5 & 15 & 36,43 & 8,67 & $25,66 \mathrm{~s} / \mathrm{d} 47,19$ & \\
\hline
\end{tabular}

Based on table 3 above it is obtained that the statistical test results obtained $p$ value $=$ 0.0005 , meaning that in alpha $5 \%$ it can be concluded that there are differences in the protective power between the four concentration groups of fragrant lemongrass experiments at 0 to the fifth. Further analysis to the concentration at 0 hours proved that a significantly different group was a concentration of $75 \%$ by $30 \%$, a concentration of $75 \%$ by $15 \%$, further analysis at the first hour of treatment proved that a significantly different group was a concentration of $75 \%$ by $45 \%, 75 \%$ concentration with $30 \%, 75 \%$ concentration with $15 \%$. Whereas in the second hour of treatment can prove that the concentration of $75 \%$ by $15 \%$. At the time of the third hour treatment can prove concentration of $75 \%$ with $60 \%$, concentration of $75 \%$ with $30 \%$, concentration of $75 \%$ with $15 \%$, for the treatment time of the fourth hour can prove that concentration of $75 \%$ with $30 \%$, concentration of $75 \%$ with $15 \%$ The last treatment at the fifth hour can be proven that the concentration of $75 \%$ with $30 \%$, the concentration of $75 \%$ with $15 \%$. Based on the above results, the most effective concentration of citronella extract to be used as a replication is at a concentration of $75 \%$ from $0^{\text {th }}$ to $5^{\text {th }}$ hours of treatment.

\section{b. Effectiveness Soursop Seed Extract (Annona muricata $L$ ) as reppelent}

Tabel 4: Effectiveness Soursop Seed Extract (Annona Muricata L)

\begin{tabular}{cccccc}
\hline $\mathbf{0}^{\text {th }}$ Hour & Concentration $\mathbf{( \% )}$ & Mean & SD & $\mathbf{9 5} \% \mathbf{C I}$ & $\boldsymbol{p}$ value \\
\hline 1 & 100 & 100 & 0.00 & $100.0 \mathrm{~s} / \mathrm{d} 100.0$ & \\
2 & 80 & 97.51 & 1.72 & $95.36 \mathrm{~s} / \mathrm{d} 99.65$ & \\
3 & 60 & 96.50 & 1.36 & $94.79 \mathrm{~s} / \mathrm{d} 98.20$ & 0.0005 \\
4 & 40 & 94.07 & 2.14 & $91.14 \mathrm{~s} / \mathrm{d} 98.20$ & \\
5 & 2010077 & 82.54 & 4.01 & $77.56 \mathrm{~s} / \mathrm{d} 87.52$ & \\
\hline $\mathbf{1}^{\text {st }}$ Hour & & & & & \\
\hline 1 & 100 & 99.51 & 1.09 & $98.15 \mathrm{~s} / \mathrm{d} 100$ & \\
2 & 80 & 96.51 & 1.38 & $94.79 \mathrm{~s} / \mathrm{d} 98.22$ & \\
3 & 60 & 95.98 & 1.41 & $94.23 \mathrm{~s} / \mathrm{d} 97.73$ & 0.0005 \\
4 & 40 & 94.03 & 1.32 & $92.39 \mathrm{~s} / \mathrm{d} 95.67$ & \\
5 & 20 & 82.49 & 1.79 & $80.26 \mathrm{~s} / \mathrm{d} 84.72$ & \\
\hline $\mathbf{2}^{\text {nd }}$ Hour & & & & & \\
\hline 1 & 100 & 98.48 & 1.38 & $96.77-100$ & \\
2 & 80 & 95.94 & 1.35 & $94.26-97.63$ & \\
3 & 60 & 95.41 & 2.17 & $92.70-98.11$ & 0,0005 \\
4 & 40 & 92.49 & 1.77 & $90.29-94.69$ & \\
5 & 20 & 79.69 & 1.83 & $77.41-81.97$ & \\
\hline $3^{\text {rd }}$ Hour & & & & \\
\hline 1 & 100 & 96.46 & 1.39 & $94.73-98.87$ & \\
2 & 80 & 93.84 & 1.32 & $92.30-95.59$ & \\
3 & 60 & 93.00 & 1.11 & $91.61-94.38$ & 0.0005 \\
4 & 40 & 90.94 & 1.41 & $89.18-92.71$ & \\
5 & 20 & 77.28 & 1.60 & $75.29-79.27$ & \\
\hline
\end{tabular}




\begin{tabular}{cccccc}
\hline $\mathbf{4}^{\text {th }}$ Hours & \multicolumn{5}{c}{} \\
\hline 1 & 100 & 96.40 & 1.40 & $94.66-98.15$ & \\
2 & 80 & 93.34 & 1.33 & $91.68-95.00$ & \\
3 & 60 & 90.30 & 2.10 & $87.69-92.91$ & 0,0005 \\
4 & 40 & 87.87 & 1.20 & $86.38-89.36$ & \\
5 & 20 & 67.33 & 3.40 & $63.10-71.56$ & \\
\hline $\mathbf{5}^{\text {th }}$ Hours & & & & & \\
\hline 1 & 100 & 95.42 & 2.07 & $92.84-98.00$ & \\
2 & 80 & 92.88 & 1.19 & $91.68-95.00$ & \\
3 & 60 & 89.89 & 1.77 & $87.69-92.91$ & 0.0005 \\
4 & 40 & 85.07 & 1.77 & $82.86-87.27$ & \\
5 & 20 & 61.60 & 2.33 & $58.70-64.50$ & \\
\hline
\end{tabular}

Based on table 4, all statistical test results obtained $p$ value $=0.000, \mathrm{p}$ value $\leq$ alpha $(0.0000 \leq$ 0.05 ) it can be concluded that there are differences in the protective power of the five concentrations used and all observations. Concentrations that have significant differences are concentrations of $20 \%$ with $100 \%$ and concentrations of $40 \%$ with $100 \%$ at 0 hours of observation. In the first hour of observations obtained $60 \%$ concentration with $100 \%, 80 \%$ concentration with $100 \%$. In the second hour the most effective observations were a concentration of $20 \%$ with $100 \%$ and a concentration of $40 \%$ with $100 \%$. Then for the third hour of observation the most effective concentration is a concentration of $40 \%$ with $100 \%$, and a concentration of $60 \%$ with $100 \%$. At the fourth hour the most effective observations were a concentration of $40 \%$ with $100 \%$, and a concentration of $60 \%$ with $100 \%$. The last observation time is the fifth hour that the most effective concentration of pliers is a concentration of $40 \%$ with $80 \%$, a concentration of $40 \%$ with $100 \%$, and a concentration of $60 \%$ with $100 \%$.

\section{Discussion}

4.1 Protection Power of Citronella Extract and Soursop Seed Extract a. The protective power of citronella extract against the bite of aedes aegypti mosquito

Based on the results of experiments conducted, it is known that the number of mosquitoes that landed on the hands of probandus smeared with citronella extract (Cymbopogon winterianus jowitt)0th increased from the to the $5^{\text {th }}$ hour. can attract mosquitoes to perch on the hands smeared with citronella with a concentration of $15 \%$ while the least attracting mosquitoes alighted are those smeared with citronella with a concentration of $75 \%$. During this time, citronela extract (Cymbopogon $S p$ ) is widely used by the public as a cooking spice and ingredients for mixing herbs. However, it turns out, citronella extract has other benefits, especially in the stem and leaves that can be used as mosquito repellents. [13]

Various types of plants can be used as natural larvicides, where citronella is one of them that can be utilized more content contained in the stems and leaves. The main content is in the form of citronella and geraniol, where citronella is toxic and will cause death of larvae because the larvae are constantly dehydrated. Geetha (2014) [14] from the Faculty, Department of Microbiology, Saveetha Dental College \& Hospitals, Chennai highlighted the importance of essential oils from Cymbopogon winterianus Jowitt, Azadirchata indica, Lavandula angustifolia, Mentha piperita for the control of vector-borne diseases. The essential oil contained in it is a mixture of volatile hydrocarbons with a diversity of functional groups, and this provides the ability to repel mosquitoes. The above research results are in line with research by Manurung (2013). [15] mosquitoes that bite at $1 \%$ 
concentration treatment there are 2 tails and $75 \%$ protection power, mosquitoes that bite at $2 \%$ concentration treatment there are 2 tails, no mosquitoes bite at $3 \%$ concentration treatment, and no mosquitoes that bite at concentration 4 treatments $\%$.

According to the researchers' assumptions that the greater the concentration of citronella extracted as repellent, the less the attraction of mosquitoes to perch so that the higher the protective power produced by the citronella. This is the basis for making citronella as an alternative to avoid mosquito bites, especially the Aedes aegypti mosquito which is a vector of dengue mosquitoes which is an infectious disease that can endanger the health and lives of sufferers.

Protection is the ability to reject or protect objects that have been smeared with an ingredient either cream or liquid that results in protection against an object be it an insect or insect another. [16] based on research published in the Journal of Vector Ecology states that among the four oils without vanillin, citronella gives repellency to Aedes aegypti for three hours while turmeric and kaffir lime only provide protection for 1 hour. The protective power of citronella extract (Cymbopogon winterianus jowitt) showed that the highest protective power was $100 \%$ at a concentration of $75 \%$ the 0 th hour where the protection power decreased to $92.62 \%$ at the 5 th hour. This shows that citronella extract has the potential as a repellent against Aedes aegypti mosquitoes, with a protection capacity of more than 90\%, where government regulations through the Department of Agriculture's Pesticide Commission (1995) require that an anti-mosquito lotion can be said to be effective if the protection power is at least $90 \%$ and can last up to 6 hours.

\section{b. Protection Power of soursop seed extract against mosquito bites aedes aegypti}

The repellent test of Soursop Seed Extract (Annona muricata L) is carried out by inserting volunteer hands into the test cage for 5 minutes alternately between the right hand and the left hand. The right hand as a control (without smeared with Soursop seed extract (Annona muricata L) and the left hand as a treatment (smeared with Soursop seed extract (Annona muricata L). Based on the table of the number of Aedes aegypti mosquitoes that land on the hand with various concentrations of soursop seed extract and the length of time observations, there are differences in the average number of mosquitoes perched. Right hand more mosquitoes perched compared to the left hand.In the left hand at 5 hours more mosquitoes perched than at the $0^{\text {th }}$ hour.

Extracts are activities to withdraw soluble chemical contents so that it is separated from the insoluble material with liquid solvents contained in natural materials. The purpose of extraction is to attract and separate compounds contained in the material both from plants, animals and marine biota by using organic solvents.Masteration is one of the simplest extraction methods. Meseration is done by soaking the symptomatic powder in pen fluid yari The solvent liquid entering the cell creates a difference in concentration between the solution inside and outside the cell. Low concentration solutions are in while high concentrations are pushed out of the cell. The searching liquid used can be water, ethanol, water-ethanol or other solvents. [17].

The main active compounds of soursop seeds are annonacin and squamocin which are classified ascompounds acetogenin. The compound acetogenin has quite effective toxicity against insects from theorder Diptera that is cytotoxic and neurotoxic. The compound acetogenin can inhibit the action of the NADH enzyme in mythondria, causing the death of larvae, as well as being contact poisons and stomach poisons in insects [18] compounds Acetogenin in essential oils of soursop seed extract function as repellent, chemical compounds 
proven to affect locomotor activity. The odor contained in essential oils seep into the pores of the skin and the arena of body heat and and the environment, essential oils will evaporate into the air.

According to the researchers assumptions, the number of Aedes aegypti mosquitoes that perch depends on the large concentration of soursop seed extract, the higher the concentration of the more compounds acetogenin contained and the less number of mosquitoes that perch. While the longer the exposure time, the less the essential oil content, this is due to the nature of essential oils can evaporate when there is an increase in temperature.

\subsection{Effectiveness of Citronella Extract and Soursop Seed Extract}

\section{a. Effectiveness of Citronella Extract (Cymbopogon winterianus jowitt)}

Research on the protection power of mosquito bites Aedes aegypti at various concentrations is important to be done as an effort to prevent (repellent) the spread of dengue hemorrhagic fever (DHF). Utilization of natural ingredients, one of which is by using citronela extract which can minimize the use of anti-mosquito (repellent) which contains chemicals. After statistical analysis using the Anova test to find out the difference in protective power in the treatment group and in each concentration where $p=0.0005$, it means that in alpha $(\alpha=5 \%)$ it can be concluded that there is a significant difference in the protective power in the tested treatment group and where $p$ $=0.0005$, it means that in alpha $(\alpha=5 \%)$ it can be concluded that there is a significant difference in protective power at each test time.

This shows that the protective power of citronella extract (Cymbopogon winterianus jowitt) is influenced by the concentration of citronella extract and the time of testing. Of the five concentrations used $(75 \%, 60 \%, 45 \%, 30 \%$, and $15 \%)$ the most effective concentration as a repellent mosquito repellent is $75 \%$ because on the hands smeared with lemongrass scents $75 \%$ at least occupied by mosquitoes. The results of this study are in line with research conducted by Safaruddin, et al from Hasanuddin University who stated that the lemongrass extract $10 \%$ concentration has a very good repellant effectiveness. Therefore the higher the concentration of citronella extract $C$. nardus (L.) Randle, the better it is used as a repellent.

\section{b. Effectiveness of Soursop Seed (Annona muricata L)}

Research on the effectiveness of soursop seed extract (Annona muricata L) as a Natural Repellent against Aedes Aegypti mosquitoes with various concentrations was carried out as one of the efforts to prevent DHF. Utilization of natural ingredients such as soursop seeds can minimize the use of chemical repellent. Research by Nurlaeli (2016) [20] on the Effectiveness of Soursop Leaf Extract (Annoma muricata L) as Repellent Mosquito Aedes aegypti, states that the concentration of 95\% has a protective power of $75.01 \%$ during a $6^{\text {th }}$ hour observation. Another study by Rizma (2017) [19] about the differences in the concentration of Soursop Seed Extract (Annoma muricata $L)$ as a Repellent Against the Aedes aegpty mosquito repellent, stated that the concentration of $35 \%$ had a protective power of $94.85 \%$ over 3 hours of observation.

At a concentration of $20 \%$ the content of the compound acetogenin was less than that of other concentrations, at 0 hours the average protection was $82.54 \%$. These 
results indicate that at a concentration of $20 \%$ is not effective as a repellent, because it has a protective power $<90 \%$. At the fourth hour, the concentration of $40 \%$ had a protective power of $87.87 \%$. These results indicate that at a concentration of $40 \%$ is not effective as a repellent, because it has a protective power $<90 \%$. At the 5 th hour, the concentration of $60 \%$ had a protective power of $89.89 \%$. These results indicate that at a concentration of $60 \%$ is not effective as a repellent, because it has a protective power $<90 \%$. At hour 5 th concentrations of $80 \%$ and $100 \%$ had protective power of $92.88 \%$ and $95.42 \%$, respectively. These results indicate that at concentrations of $80 \%$ and $100 \%$ effective as repellent.

According to the researcher's assumptions, the higher the concentration used, the greater the effectiveness of soursop seed extract as a repellent and the longer the protection power. According to the Pesticides Commission, Repellent it is considered effective if the observation is carried out for 6 hours and the protection results are above $90 \%$. The results of this study indicate that the concentrations of $80 \%$ and $100 \%$ have protective power respectively of $92.88 \%$ and $95.42 \%$ for 6 hours of observation. Concentration of $100 \%$ has the highest protection power of $95.42 \%$, it's can be concluded concentration.

\section{Conclusion}

Based on the results of research that has been done, and it can be concluded that the average number of mosquitoes that landed on hands that have been smeared with citronella extract (Cymbopogon winterianus Jowitt) at a concentration of $75 \%$ at the 0 th hour is 0 tails and the number increased until the 5 th hour with a total of 8 . The protective power of fragrant citronella extract (Cymbopogon winterianus jowitt) is influenced by the concentration of fragrant lemongrass extract and testing time.

The higher the concentration of fragrant citronella extract used the more effective as a repellent (mosquito repellent). The highest number of mosquitoes perched on the skin after soursop seed extract (Annona muricata L) with a concentration of $20 \%$ in the fifth hour was 15, while the lowest was at a concentration of $100 \%$ at the 0 th hour where no mosquitoes alighted. The concentration of Soursop Seed Extract (Annona muricata L) which is effective as a natural repellent for 6 hours of observation is the concentration of $80 \%$ and $100 \%$ with protective power respectively $92.88 \%$ and $95.42 \%$.this research is expected to be the basis for further research specifically relating to the respondents made from nature and with the same concentration

\section{References}

[1] Profil Kesehatan Kemenkes RI. 2014.

[2] Profil Kesehatan Sumatera Barat, 2016.

[3] Profil Kesehatan Sumatera Barat, 2015.

[4] Profil Kesehatan Dinas Kesehatan Kota Bukitinggi, 2017.

[5] Sembel, D. T. 2009. Entomologi Kedokteran. Yogyakarta: Penerbit Andi.

[6] Yuliani,S.H, 2005. Formulasi Gel Repelen Minyak Atsiri Tanaman Akar Wangi (Vetivera zizanioidesi (L) Nogh). Majalah Farmasi Indonesia, 16(4), 197-203. Falkutas Farmasi Universitas Sanata Dharma 
[7] Wahyuningtyas, E. 2004. Study Data Proteksi Serei Wangi (Cymbopogon nardus) sebagai Repellent terhadap Nyamuk Ae. Aegypti. Bogor. Sudarmo, Demam Berdarah Dengue, Jakarta:Fakultas Kedokteran Indonesia, (1983).

[8] Kadinan, A. 2003. Tanaman Pengusir dan Pembasmi Nyamuk. Jakarta : Argomedia Pustaka.

[9] Ardraviz. 2012. Khasiat Tanaman Sirsak Untuk Kesehatan.. Diakses 5 Februari. Tersedia http://ardra.biz/kesehatan/khasiat-sirsak.

[10]Yasril. 2011. Uji Toksisitas Ekstrak Biji Sirsak (Annona muricata Linn) Terhadap Larva Aedes aegypty. Perpustakaan Universitas Indonesia. UI-Tesis. Diakses tanggal 5 Februari. Tersedia http://pdfcast.org.

[11]Manurung, R., Chahaya, I., Dharma, S. 2012. Pengaruh Daya Tolak Perasan Sereh Wangi (Cymbopogon nardus (L) Randle) terhadap gigitan Nyamuk Aedes Aegypti.

[12]Tohir, A. 2010. Teknik Ekstraksi dan Aplikasi Beberapa Pestisida Nabati Untuk Menurunkan Palatabilitas Ulat grayak (Spodoptera litura fabr) di Laboratorium. Buletin Teknik Pertanian Vol. 5, No.1, 2010. Diakses tanggal 5 Februari. Tersedia http://pustaka.litbang.deptan.go.id.

[13] Ginanjar, G. 2012. Demam Berdarah A Survival Guide. Universitas Padjajaran Bandung.

[14]Utami, B. T., Sri. Uji Toksisitas Ekstrak Biji Sirsak (Annona muricata Linn) Terhadap Larva Aedes aegypti. Tesis. Jakarta: UI press. 2000.

[15] Manurung, R., Chahaya, I., Dharma, S. 2012. Pengaruh Daya Tolak Perasan Sereh Wangi (Cymbopogon nardus (L) Randle) terhadap gigitan Nyamuk Aedes Aegypti.

[16] Tjitrosoepomo, G. 201. Taksonomi Tumbuhan (Spermatophyta). Yogyakarta : Gajahmada University Press.

[17] Depkes RI. 2002. Demam Berdarah Penyebab Kematian Terbesar di RI : Jakarta.

[18] Rosmayanti, K. 2014. Uji Efektifitas Ekstrak Biji Sirsak (Annona muricata L.) sebagai Larvasida pada Aedes aegypti Instar III/IV. Skripsi. Jakarta : UIN Syarif Hidayatullah.

[19] Risma RF, Nadyawatie WN. 2017. Perbedaan Berbagai Konsentrai Ekstrak Biji Sirsak (Annona muricata) sebagai Repellent terhadap Daya Tolak Namyk Aedes aegypti. Jurnal Kesehatan Vol.9 No.2 Tahun 2017 